\title{
Developing Digital Printing Sticky Media for Chemistry Learning of Senior High School Students on Inorganic Compound Nomenclature Subject
}

\author{
Mayda Parlinawati \\ Chemical Education Program \\ Teacher Training and Education \\ Faculty of Mulawarman University \\ Samarinda, Indonesia \\ maydaparlinawati81@gmail.com
}

\author{
Mukhamad Nurhadi \\ Chemical Education Program \\ Teacher Training and Education \\ Faculty of Mulawarman University \\ Samarinda, Indonesia \\ nurhadi1969@yahoo.co.id
}

\author{
Zulkarnaen \\ Physic Education Program \\ Teacher Training and Education \\ Faculty of Mulawarman University \\ Samarinda, Indonesia \\ zul67belitungu@gmail.com
}

\begin{abstract}
This study aimed to determine the feasibility of digital printing sticky media to be used as a learning media in the subject of inorganic compound nomenclature. This research was categorized as a research and development (R\&D) which adopted the Borg and Gall model. This research was carried out in seven steps, namely potential and problems, data collection, product design, design validation, design revision, product tryout, and analysis and reporting. Data analysis technique was using mixed method analysis. The media was applied in a classroom consist of 35 of tenth grade natural science students of SMAN 10 Samarinda, East Kalimantan Province, Indonesia. During the tryout of the media in teaching and learning process, observations on students' activities and students' responses were conducted. The results showed that the developed digital printing sticky media for inorganic compound nomenclature subject had very valid criteria constructed with a percentage of $95.8 \%$. The practicality of the media in chemistry learning was $87.6 \%$ with a very good category and students also showed a positive response to the media. Thus, it can be concluded that the developed digital printing sticky media meets is feasible to be used in learning on inorganic compound nomenclature subject.
\end{abstract}

Keywords: development, sticky media, inorganic compound nomenclature

\section{INTRODUCTION}

Chemistry is one of the subjects of natural sciences that become a means or a forum for students to learn about themselves and their surroundings, as well as developments in their application in daily life. Chemistry is an abstract subject because some chemistry topics require understanding by memorizing formulas and properties of substances both physical and chemical properties, such as organic chemistry, atomic structure, biochemistry, and elemental chemistry [1].

Many students experienced difficulty in learning chemistry since they need to connect various abstract concepts. Therefore, student's activeness and understanding on learning chemistry will be affected when they felt bore on a prolonged basis. Various attempts have been made to increase the activeness of students. Efforts to improve, change and renewal in the field of education are also the responsibility of teachers as one component of teaching and learning activities in schools [2].

One of topics in chemistry is the nomenclature of compounds. According to Indonesian curriculum, the nomenclature of an inorganic compound is conducted at second semester of tenth grade students. In understanding the concept of chemical compound nomenclature, students must know about the names of elements, elements symbol, charges, oxidation numbers, and the rules of naming compounds and writing their chemical formulas. These prerequisites need to be known and understood so that students do not experience difficulties in understanding the chemical nomenclature concept.

Based on interviews with several chemistry teachers in Samarinda, East Kalimantan Province, Indonesia, namely SMAN 4 and SMAN 10 Samarinda, the teacher uses conventional method to explain the nomenclature topic for inorganic compounds. They explain and deliver the subject by using blackboard and/or a power point. The learning process is teacher centered only. Learning process is conducted by explaining theory, giving examples and ended by practicing. The teacher teaches students using direct learning model without instructional media, only by using the lecture and assignment methods. The absence of creative and innovative media makes students less active in the learning process. Moreover, the learning atmosphere becomes less pleasant, students gives less attentions. The conditions above lead to less trained students in developing independent abilities [3].

Media are all physical tools that can present messages and stimulate students to learn [4]. The media as a component of the learning strategy is a container of messages that the source or supplier wants to pass on to the target or recipient of the message, and the material to be conveyed is the learning message, and that the goal to be achieved is the learning process [5]. The media is said to be good if it meets three criteria, which are: valid, practical, and effective [6].

Digital printing paste media is one example of graphic media. Graphic media is a visual media that presents facts, ideas or ideas through the presentation of words, numbers, formulas, symbols or images [7].

In connection with the above explanation, researchers feel the need to try to develop innovative learning media on learning chemistry for compound nomenclature material. The chemical nomenclature sticky paste is designed so that students can explore their abilities so that they can process and digest the information obtained while the teacher is explaining. It is hoped that this digital printing paste media can arouse motivation and train students to independently find the compound nomenclature concept by attaching and 
pairing chemical names and chemical formulas in the sticky media so that students are actively involved in learning.

Based on the problems raised above, the researcher tried to develop digital printing sticky media for chemistry learning of Senior High School Students on the subject of inorganic compound nomenclature.

\section{METHOD}

This was a research and development type of research which adopted the Borg and Gall model. This research was carried out in seven steps; consist of 1) potential and problems, 2) data collection, 3) product design, 4) design validation, 5) design revision, 6) product tryout, 7) analysis and reporting [8]. The media was applied in a classroom consist of 35 of tenth grade natural science students of SMAN 10 Samarinda, East Kalimantan Province, Indonesia. Data analysis technique was using mixed method analysis. Data collection techniques in this study were validation sheets from constructing media experts and during the media trials in learning observations were made on student activities and questionnaire sheets on student responses towards the developed media. The data obtained in this study by calculating the media feasibility score (validity) from the results of the construct validation expert and the practicality analysis of the media through individual student assessment questionnaire data. The formulas used are as follows:

1. The results of construct expert validation using the percentage formula [9]

$$
\mathrm{P}=(\mathrm{A} / \mathrm{B}) \times 100 \%
$$

where $\mathrm{A}$ is total number of validator score and $\mathrm{B}$ is highest total number of score. Then learning media validation criteria is shown in table 1 [10].

2. Practicality Analysis of Media using Formulas percentage of rating $(\%)$ [11]

$$
\mathrm{P}=(\mathrm{A} / \mathrm{B}) \times 100 \%
$$

where $\mathrm{A}$ is number of answer score obtained and B is maximum score number. The percentage classification of practicality of the media is shown in table 2 [12].

\section{RESULTS AND DISCUSSION}

The results of media expert validation are focused on the appearance or presentation seen from the perspective of the media. This validation is carried out in several stages. Each stage was revised according to expert input. In the final stage an evaluation is obtained from filling out the questionnaire by experts, the questionnaire data is analyzed to determine the validity of the media in terms of media.

Table 3 shows that the digital printing patch nomenclature of the developed compound has a very valid level of eligibility in terms of the feasibility of the media based on the assessment of the media constructs including the quality of the media, the suitability of the media and the attractiveness of the media. The quality of media components seen from media design, media size and quality of digital printing outboard cards obtained a percentage of $100 \%$ with very valid criteria which means that the aspects of media quality are in accordance with the level of eligibility/validity. In the aspect of media suitability including the suitability of the media with core competency, basic competency, indicators of learning outcomes, students worksheets and the ability level of students obtained a percentage of $91.67 \%$ this shows the developed media is in accordance with basic competency and learning objectives so that from the aspect of media suitability has a very valid level of eligibility. The attractiveness aspect of media presentation in terms of media appearance, the ability of the media to motivate students and the ease of the process of using media obtained a percentage of $95.83 \%$ with very valid criteria. This means that it is judged from the aspect of the attractiveness of the presentation of the digital printing paste that has been developed in accordance with the level of eligibility / validity of the media.

The results of media validation by media constructs experts obtained a percentage of ratings of $95.8 \%$ with very valid criteria in terms of aspects of the quality of the media, aspects of the suitability of the media with the material and aspects of the attractiveness of the media presentation.

Observation is used to observe student activities in learning activities. The results of observations of student activity data analysis are a description of student activities in the learning process using media assistance. Observations were made by an observer, a chemistry teacher, using a student observation sheet.

The analysis of the practicality of the media carried out on 35 students from tenth grade of natural science students at SMAN 10 aims to find out how the digital printing sticky compound nomenclature can be used by students well during teaching and learning activities taking place. The results of student response can be seen from the table 4 .

TABLE I. MEDIA VALIDATION CRITERIA LEARNING

\begin{tabular}{|c|c|}
\hline Percentage (\%) & Criteria \\
\hline $85.01-100$ & Very Valid \\
\hline $70.01-85.00$ & Valid \\
\hline $50.01-70.00$ & Less Valid \\
\hline $01.00-50.00$ & Not Valid \\
\hline
\end{tabular}

TABLE II. PERCENTAge Classification

\begin{tabular}{|c|c|}
\hline Percentage (\%) & Criteria \\
\hline $80-100$ & Very Good \\
\hline $70-79$ & Good \\
\hline $60-69$ & Good Enough \\
\hline $50-59$ & Less Good \\
\hline $0-49$ & Not Good \\
\hline
\end{tabular}

TABLE III. Media Validation Results by Constructing Media EXPERTS

\begin{tabular}{|c|l|c|}
\hline Validation & \multicolumn{1}{|c|}{ Aspects } & $\begin{array}{c}\text { Score } \\
(\boldsymbol{\%})\end{array}$ \\
\hline $\begin{array}{c}\text { Validation by } \\
\text { the construct } \\
\text { expert }\end{array}$ & 1.The media quality & 100 \\
& $\begin{array}{l}\text { 2.The media compatability } \\
\text { presentation }\end{array}$ & 91.67 \\
\hline
\end{tabular}




\section{REFERENCES}

\begin{tabular}{|c|c|c|}
\hline Measurements & Percentage $\mathbf{( \% )}$ & Category \\
\hline Student activities & 89.2 & Very Good \\
\hline Student responses & 87.6 & Very Good \\
\hline
\end{tabular}

The results of limited trials at SMAN 10 Samarinda showed that the practicality of the media for use in chemistry learning was $87.6 \%$ with a very good category and students also showed a positive response to the digital printing compound nomenclature media.

Based on the results of student interviews on the use of compound printing digital printing nomenclature, students feel happy learning chemistry, students are proactively involved and the learning atmosphere becomes more enjoyable so as to provide a more meaningful learning experience. In addition, by learning to use the media, students become easier to understand the material and quickly remember the names and chemical formulas of inorganic compounds.

\section{CONCLUSION}

Based on result, it can be concluded that the digital printing sticky media developed meets valid $(95.8 \%)$ and practical $(87.6 \%)$ categories so that it is feasible to be used in learning on inorganic compound naming.

\section{ACKNOWLEDGMENT}

First authors are grateful to SMA Head of SMAN 10 Samarinda, East Kalimantan Province, Indonesia that supported the implementation of this research.

[1] Effendy, "Efforts to overcome concept mistakes in chemistry learning using cognitive conflict strategies," Chemical Communication Media, vol. 2, 2002, pp. 1-12.

[2] Mulyatun, "Virtual chemistry laboratory: alternative learning chemistry to improve student learning outcomes of tadris chemistry IAIN Walisongo Semarang," Journal of chemical education innovation, vol. 6, 2012, pp. 935-946.

[3] D. Juniayanti, "The effect of self regulated learning model assisted by environmental media on science learning motivation," E-Journal PGSD, vol. 4, 2016.

[4] A. S. Sadiman, Education media understanding, developing and utilizing it, Jakarta: Raja Grafindo, 2006.

[5] Trianto, Introduction to research on professional development in personnel education, Jakarta: Kencana Prenada Media Group, 2007.

[6] V.D. Akker J., Principles and methods of development research, London: Kluwer Academic Publisher, 1999.

[7] M.F. Siburian and Jupriadi, "Effectiveness of using graphic media to improve science learning outcomes," Formative Journal, vol. 6, 2016, pp. 125-133.

[8] Sugiyono, Educational research methods, Bandung: Alfabeta Publisher, 2018.

[9] Widoyoko, Research instrument designing techniques, Yogyakarta: Pustaka Pelajar, 2012.

[10] S. Akbar, Learning instrument, Bandung: PT. Remaja Rosdakarya, 2013.

[11] N. Sudjana, Statistical method, 6th ed., Bandung: Tarsito, 2005.

[12] A. Fathur, "Quantitative data analysis techniques," Available:http://mabadik.wordpress.com./2010/07/10/teknik-analdataquantitative/. Accessed on 8 January 2013. 